\title{
Breast cancer screening: time to target women at risk
}

\author{
P Hall ${ }^{\star}, 1$ and D Easton ${ }^{2,3}$ \\ ${ }^{1}$ Department of Medical Epidemiology and Biostatistics, Karolinska Institutet, Nobels väg 12A, P.O. Box 281, SE-171 77 Stockholm, \\ Sweden; ${ }^{2}$ Strangeways Research Laboratory, Department of Oncology, University of Cambridge, Worts Causeway, Cambridge \\ CB1 8RN, UK and ${ }^{3}$ Strangeways Research Laboratory, Department of Public Health and Primary Care, University of Cambridge, \\ Worts Causeway, Cambridge CB1 8RN, UK
}

A short version of the Marmot et al (2013) report published in full in this issue of British Journal of Cancer was previously published in The Lancet (Independent UK Panel on Breast Cancer Screening, 2012) and criticised by authors of 10 letters published in The Lancet on 9th March 2013 (The Lancet, 2013). The authors of the letters argued that some studies in the meta-analyses were better than others, that advances in treatment reduces the effect of screening substantially, that cause of death was not correctly registered, that the report panel did not take background rates of breast cancer mortality into consideration, that they used an inappropriate follow-up period, that effect of mammography screening is an area of uncertainty, that many assumptions are needed, that estimates of overdiagnosis were too high or too low, that data were presented in favour of screening, that screening actually increases breast cancer mortality and many more remarks of similar kind. The authors of the report politely and correctly addressed each comment.

The surprising fact is not that a report on the pros and cons of mammography screening is challenged, but that we still discuss mammography screening as if it will never change and always stay the same. Normally when something is not working properly, we try to find ways of improvement. Most areas within oncology have developed quite dramatically over the years. Within breast cancer, therapeutic advances in radio-, chemo- and hormonal therapy has decreased recurrence rate and increased cause-specific survival. Over the last decade, antibodies have introduced the concept of targeted and individualised therapy. An oncologist would today never rely simply on an X-ray, but use CT, MRI, PET, etc for proper diagnostics and follow-up.

All medical interventions, diagnostic or therapeutic, should do more good than harm. In addition, they have to be cost effective and acceptable to society, patients and health-care providers. Suppose we agree that early detection of a disease is generally better than postponing diagnosis and therapy, and that this leads to a decrease in breast cancer mortality (estimated to be $20 \%$ by the review) and also to a significant rate of overdiagnosis (estimated $11 \%)$, it raises the following questions: how to make screening more efficient? Is it possible to increase sensitivity and specificity of the tests, to decrease the number of false positive and negative test results? How do we identify the fatal cancers? Could we find means to target those woman who are most likely to benefit from screening and avoid spending time and money on those in whom we merely induce anxiety? Questions like these are seldom heard in the screening debate.

Mammography is an imaging technique that is dependent on identifying a contrast between a malignant tumour and the surrounding normal breast tissue. Mammography screening has been used in more or less the same way over the past 40 years and very little has been done to increase efficiency. Age of entry into the programme and screening intervals are discussed, but most programmes assume that the risk of breast cancer is solely dependent on age, that is, a women will benefit equally from screening as long as she is within a certain age range. However, there are many other factors that determine a woman's risk of breast cancer. Mammographic density is a comparatively simple measure of individual breast cancer risk. Mammographic density measures the proportion of non-fatty tissue in the breast - women with very dense breast have several times the risk of breast cancer compared to women with low density. Women with high mammographic density are in effect hit twice; they have a dramatically increased risk of breast cancer and, due to increased density, a lower likelihood of having a cancer detected. It therefore seems like an intuitive next step to move from age-based to riskbased screening only based on mammographic density and times are changing. US states have begun passing laws that requires clinicians to tell women if they have dense breasts or not. Under those laws, women with dense breast must be told that they have an increased risk of breast cancer and that a cancer can hide in the 
density. This should lead to additional screening tests such as ultrasound and MRI.

In addition, there are many other genetic and non-genetic markers for breast cancer risk. Risk-based screening is already routine for women with a strong family history and/or carry a $B R C A 1$ or $B R C A 2$ mutation; the principle could be extended to utilise other markers. Nearly 80 common genetic variants for breast cancer have now been identified, and collectively these identify $1 \%$ of women with a risk more than three times the average (Michailidou et al, 2013). Many more such variants are likely to be identified in the coming years. Several breast cancer risk models including BOADICEA, Tyrer-Cuzick and Gail already exist and are utilised widely in genetic counselling and prevention trials; some would argue that the current models have low predictive power, but combining the effects of genetic markers, lifestyle risk factors and mammographic density should lead to tests with useful discriminatory power.

A more nuanced risk-based screening programme would involve women at higher risk being screened from a younger age, or more intensively, or with additional modalities (e.g., MRI), while women at lower risk would be screened less often or not at all. The obvious advantage is that resources are targeted on women with the highest likelihood of benefit while at the same time reducing screening interventions for women at lower risk, thus producing more benefit at a lower cost (Pashayan et al, 2011). Moreover, we also know that both genetic and non-genetic risk factors can, to some extent, predict the risk of specific tumour subtypes as recently shown (Garcia-Closas et al, 2013). This information might enable the rate of overdiagnosis to be reduced as well.

While individualised screening is already accepted in the context of women with a family history, there are clearly many challenges to be faced before this model could become a reality in national screening programmes. The public tolerability is crucial but also probably the least problematic. For decades, perfectly healthy individuals are 'screened' for factors that influence the risk of cardiovascular disorders and measurements of blood lipids and blood pressure fully accepted. The organisational aspects are challenging. If genetic and other risk assessments were extended to all women, what form of counselling would be available? Most countries lack the infrastructure needed to handle of this massive information exchange. The professional acceptability of a change to an individualised screening programme is difficult to predict, although again the acceptance of individualised intervention for cardiovascular disease provides a model. On top of all this there are ethical, legal and social considerations to be taken into consideration.

Finally, we have not even touched on what to offer women in the highest risk group. Future prediction models will identify many more women with a lifetime risk of more than $30 \%$ - classified as 'high risk' according to NICE (National Institute for Health and Clinical Excellence, 2006). Intensified screening will surely be too passive an intervention for this group. In the context of a familial history, such women would generally be offered MRI, prophylactic surgery and/or chemoprophylactics - would this also be extended to the population at large?

\section{REFERENCES}

Garcia-Closas M, Couch FJ, Lindstrom S, Michailidou K, Schmidt MK, Brook MN, Orr N, Rhie SK, Riboli E, Feigelson HS, Le Marchand L, Buring JE, Eccles D, Miron P, Fasching PA, Brauch H, Chang-Claude J, Carpenter J, Godwin AK, Nevanlinna H, Giles GG, Cox A, Hopper JL, Bolla MK, Wang Q, Dennis J, Dicks E, Howat WJ, Schoof N, Bojesen SE, Lambrechts D, Broeks A, Andrulis IL, Guenel P, Burwinkel B, Sawyer EJ, Hollestelle A, Fletcher O, Winqvist R, Brenner H, Mannermaa A, Hamann U, Meindl A,
Lindblom A, Zheng W, Devillee P, Goldberg MS, Lubinski J, Kristensen V, Swerdlow A, Anton-Culver H, Dork T, Muir K, Matsuo K, Wu AH, Radice P, Teo SH, Shu X-O, Blot W, Kang D, Hartman M, Sangrajrang S, Shen C-Y, Southey MC, Park DJ, Hammet F, Stone J, Veer LJ, Rutgers EJ, Lophatananon A, Stewart-Brown S, Siriwanarangsan P, Peto J, Schrauder MG, Ekici AB, Beckmann MW, dos Santos Silva I, Johnson N, Warren H, Tomlinson I, Kerin MJ, Miller N, Marme F, Schneeweiss A, Sohn C, Truong T, Laurent-Puig P, Kerbrat P, Nordestgaard BG, Nielsen SF, Flyger H, Milne RL, Perez JI, Menendez P, Muller H, Arndt V, Stegmaier C, Lichtner P, Lochmann M, Justenhoven C, Ko Y-D, Muranen TA, Kristiina Aittomaki K, Blomqvist C, Greco D, Heikkinen T, Ito H, Iwata H, Yatabe Y, Antonenkova NN, Margolin S, Kataja V, Kosma V-M, Hartikainen JM, Balleine R, Tseng C-C, Berg DV, Stram DO, Neven P, Dieudonne A-S, Leunen K, Rudolph A, Nickels S, Flesch-Janys D, Peterlongo P, Peissel B, Bernard L, Olson JE, Wang X, Stevens K, Severi G, Baglietto L, McLean C, Coetzee GA, Feng Y, Henderson BE, Schumacher F, Bogdanova NV, Labreche F, Dumont M, Yip CH, Taib NA, Cheng C-Y, Shrubsole M, Long J, Pylkas K, Jukkola-Vuorinen A, Kauppila S, Knight JA, Glendon G, Mulligan AM, Tollenaar RAEM, Seynaeve CM, Kriege M, Hooning MJ, van den Ouweland AMW, van Deurzen CHM, Lu W, Gao Y-T, Cai H, Balasubramanian SP, Cross SS, Reed MWR, Signorello L, Cai Q, Shah M, Miao H, Chan CW, Chia KS, Jakubowska A, Jaworska K, Durda K, Hsiung C-N, Wu P-E, Yu J-C, Ashworth A, Jones M, Tessier DC, Gonzalez-Neira A, Pita G, Alonso MR, Vincent D, Bacot F, Ambrosone CB, Bandera EV, John EM, Chen GK, Hu JJ, Rodriguez-Gil JL, Bernstein L, Press MF, Ziegler RG, Millikan RM, Deming-Halverson SL, Nyante S, Ingles SA, Waisfisz Q, Tsimiklis H, Makalic E, Schmidt D, Bui M, Gibson L, Muller-Myhsok B, Schmutzler RK, Hein R, Dahmen N, Beckmann L, Aaltonen K, Czene K, Irwanto A, Liu J, Turnbull C, Rahman N, MeijersHeijboer H, Uitterlinden AG, Rivadeneira F, Olswold C, Slager S, Pilarski R, Ademuyiwa F, Konstantopoulou I, Martin NG, Montgomery GW, Slamon DJ, Rauh C, Lux MP, Jud SM, Bruning T, Weaver J, Sharma P, Pathak H, Tapper W, Gerty S, Durcan L, Trichopoulos D, Tumino R, Peeters PH, Kaaks R, Campa D, Canzian F, Weiderpass E, Johansson M, Khaw K-T, Travis R, Clavel-Chapelon F, Kolonel LN, Chen C, Beck A, Hankinson SE, Berg CD, Hoover RN, Lissowska J, Figueroa JD, Chasman DI, Gaudet MM, Diver WR, Willett WC, Hunter DJ, Simard J, Benitez J, Dunning AM, Sherman ME, Chenevix-Trench G, Chanock SJ, Hall P, Pharoah PDP, Vachon C, Easton DF, Haiman CA, Kraft P (2013) Genome-wide association studies identify four ER negative-specific breast cancer risk loci. Nat Genet 45(4): 392-398.

Independent UK Panel on Breast Cancer Screening (2012) The benefits and harms of breast cancer screening: an independent review. The Lancet 380: 1778-1786.

Marmot G, Altman DG, Cameron DA, Dewar JA, Thompson SG, Wilcox M. The Independent UK Panel on Breast Cancer Screening (2013) The benefits and harms of breast cancer screening: an independent review. Br J Cancer 108(11): 2205-2240.

Michailidou K, Hall P, Gonzalez-Neira A, Ghoussaini M, Dennis J, Milne RL, Schmidt MK, Chang-Claude J, Bojesen SE, Bolla MK, Wang Q, Dicks E, Lee A, Turnbull C, Rahman N. Breast and Ovarian Cancer Susceptibility CollaborationFletcher O, Peto J, Gibson L, Dos Santos Silva I, Nevanlinna H, Muranen TA, Aittomäki K, Blomqvist C, Czene K, Irwanto A, Liu J, Waisfisz Q, Meijers-Heijboer H, Adank M. Hereditary Breast and Ovarian Cancer Research Group Netherlands (HEBON)van der Luijt RB, Hein R, Dahmen N, Beckman L, Meindl A, Schmutzler RK, Müller-Myhsok B, Lichtner P, Hopper JL, Southey MC, Makalic E, Schmidt DF, Uitterlinden AG, Hofman A, Hunter DJ, Chanock SJ, Vincent D, Bacot F, Tessier DC, Canisius S, Wessels LF, Haiman CA, Shah M, Luben R, Brown J, Luccarini C, Schoof N, Humphreys K, Li J, Nordestgaard BG, Nielsen SF, Flyger H, Couch FJ, Wang X, Vachon C, Stevens KN, Lambrechts D, Moisse M, Paridaens R, Christiaens MR, Rudolph A, Nickels S, Flesch-Janys D, Johnson N, Aitken Z, Aaltonen K, Heikkinen T, Broeks A, Veer LJ, van der Schoot CE, Guénel P, Truong T, Laurent-Puig P, Menegaux F, Marme F, Schneeweiss A, Sohn C, Burwinkel B, Zamora MP, Perez JI, Pita G, Alonso MR, Cox A, Brock IW, Cross SS, Reed MW, Sawyer EJ, Tomlinson I, Kerin MJ, Miller N, Henderson BE, Schumacher F, Le Marchand L, Andrulis IL, Knight JA, Glendon G, Mulligan AM. kConFab Investigators; stralian Ovarian Cancer Study GroupLindblom A, Margolin S, Hooning MJ, Hollestelle A, van den Ouweland AM, Jager A, Bui QM, Stone J, Dite GS, Apicella C, Tsimiklis H, Giles GG, Severi G, Baglietto L, Fasching PA, Haeberle L, Ekici AB, Beckmann MW, Brenner H, Müller H, Arndt V, Stegmaier C, Swerdlow A, Ashworth A, Orr N, Jones M, Figueroa J, 
Lissowska J, Brinton L, Goldberg MS, Labrèche F, Dumont M, Winqvist R, Pylkäs K, Jukkola-Vuorinen A, Grip M, Brauch H, Hamann U, Brüning T; GENICA (Gene Environment Interaction and Breast Cancer in Germany) NetworkRadice P, Peterlongo P, Manoukian S, Bonanni B, Devilee P, Tollenaar RA, Seynaeve C, van Asperen CJ, Jakubowska A, Lubinski J, Jaworska K, Durda K, Mannermaa A, Kataja V, Kosma VM, Hartikainen JM, Bogdanova NV, Antonenkova NN, Dörk T, Kristensen VN, AntonCulver H, Slager S, Toland AE, Edge S, Fostira F, Kang D, Yoo KY, Noh DY, Matsuo K, Ito H, Iwata H, Sueta A, Wu AH, Tseng CC, Van Den Berg D, Stram DO, Shu XO, Lu W, Gao YT, Cai H, Teo SH, Yip CH, Phuah SY, Cornes BK, Hartman M, Miao H, Lim WY, Sng JH, Muir K, Lophatananon A, Stewart-Brown S, Siriwanarangsan P, Shen CY, Hsiung CN, Wu PE, Ding SL, Sangrajrang S, Gaborieau V, Brennan P, McKay J, Blot WJ, Signorello LB, Cai Q, Zheng W, Deming-Halverson S, Shrubsole M, Long J, Simard J, Garcia-Closas M, Pharoah PD, Chenevix-Trench G, Dunning AM, Benitez J, Easton DF (2013) Large-scale genotyping identifies 41 new loci associated with breast cancer risk. Nat Genet 45(4): 353-361.
National Institute for Health and Clinical Excellence (2006) Familial Breast Cancer-The classification and care of women at risk of familial breast cancer in primary, secondary and tertiary care. This is a partial update of NICE clinical guideline 14. NHS [online] Available from http:// www.nice.org.uk/nicemedia/pdf/CG41NICEguidance.pdf.

Pashayan N, Duffy SW, Chowdhury S, Dent T, Burton H, Neal DE, Easton DF, Eeles R, Pharoah P (2011) Polygenic susceptibility to prostate and breast cancer: implications for personalised screening. $\mathrm{Br} J$ Cancer 104(10): 1656-1663.

The Lancet (2013) 381(9869): 799-803.

(c) (i) (2) (2) This work is licensed under the Creative Commons Attribution-NonCommercial-Share Alike 3.0 Unported License. To view a copy of this license, visit http://creativecommons. org/licenses/by-nc-sa/3.0/ 